\title{
Integrated Communication through Animated Edutainment Series: A Case of Cha-Ching
}

\section{Euiseon Jeong}

\author{
Mirae Asset Life Insurance, Seoul, Korea
}

Objectives: Recently, many companies have been emphasizing Environmental, Social, Governance (ESG) management, raising awareness of corporate social responsibility in the business ecosystem. This article presents a case-based study on how a globally operating company can communicate effectively with children and fulfill its social responsibility to its community.

Methods: This study investigates how Prudential Corporation Asia (PCA), which have been doing insurance and investment business for more than 90 years in Asia and Africa, has implemented the Cha-Ching program in line with the company's business nature. We also looked at how the company designed the communication to draw their target audience's attention and participation.

Results: Prudence Foundation developed the Cha-Ching program for financial literacy of children, aiming educating money-smart skills how they earn, save, spend, and donate. To enhance educational effectiveness, they introduced cartoon characters called the Cha-Ching band and presented series of music videos through various channels such as TV, website, SNS, school contact program. The non-profit entity has served 10 Asia and Africa communities with the program since it was incorporated in 2011.

Conclusions: Economic education using the edutainment series is very effective in inducing participants' attention and participation. Also, integrated communication is much more effective than single communication channels. Insurance companies are contributing to the national economy from the nature of the business, but they can fulfill corporate social responsibilities more actively as PCA does for children's financial literacy.

Key Words: Integrated Communication, Edutainment, Corporate Social Responsibility, Life Insurance, Cha-Ching

\section{Introduction}

A leopard can't change its spots: it means that habits made when a person is young last until s/he gets old. One of the important habits that should be formed correctly in childhood might be

Received: Apr 14, 2021 Revised: May 30, 2021 Accepted: Jun 21, 2021 Corresponding author: Euiseon Jeong Customer Service Division, Mirae Asset Life Insurance, Seoul 07330, Korea Tel: +2-3271-5550, E-mail: sally0803@hanmail.net

This is an Open Access article distributed under the terms of the Creative Commons Attribution Non-Commercial License (http://creativecommons.org/licenses/ by-nc/4.0/) which permits unrestricted non-commercial use, distribution, and reproduction in any medium, provided the original work is properly cited.

Copyright $\odot 2021$ Korean Association for Business Communication. financial habits. It is indisputable that having virtuous financial habits and responsibility is paramount for individuals living in a modern capitalist society. Some studies investigated financial literacy in a youth context. Australia's National Consumer and Financial Literacy Framework (NCFLF) mentioned that financial literacy is important for all young people in order to empower them to make informed consumer decisions and to effectively manage their personal financial resources" (Consumer and Financial Literacy Working Party, 2011, p. 5).

Based on 170-year history of its parent company Prudential plc, Prudential Corporation Asia (PCA), which has provided financial services for more than 90 years, established Prudence Foundation to fulfill its social responsibilities for the people of Asia and Africa. The non-profit corporation used cartoon 
characters to create Cha-Ching program for children's financial literacy. Given the fact that PCA is doing long-term business, decades or a lifetime of policy duration, educating children who may become prospective customers to have the right sense of economy would be substantially meaningful not only contributing to the community but also investing its future business.

\section{Life Insurance as a Financial Instrument}

A person lives exposed to various risks, such as illness, injury, and death, from birth to death. Life insurance is a financial system to prepare for economic losses caused by the unexpected incidents. Also, people need various funds according to their life cycles such as education, marriage, childcare and retirement, and they can gear up for the events through life insurance products. In short, life insurance provides not only protection functions for unforeseen risks, but also saving functions to effectively accumulate assets. As such, life insurance is characterized by a very long-term period of time to serve these financial needs.

On the other hand, an insurance contract is speculative in nature in that the payment of insurance proceeds depends on probability-based future incidents. In addition, it has more customer complaints because claim proceeds are far much bigger than premium paid and mis-selling caused by solicitors is quite frequent. Many insurance policies are sold by intermediaries such as agents or bank tellers, not by the company directly. They make customers aware the needs for protection or saving, and solicit to buy insurance products. Though they should thoroughly explain the terms and conditions of the insurance products, there are many cases where they didn't complete the duty in reality. Due to the nature of these insurance contracts, insurance has more consumer complaints than other financial sectors. According to the Financial Supervisory Service's 2020 Financial Consumer Protection Assessment, insurance companies received 13.7 percent of "poor" or "vulnerable" in the number of consumer complaints, far surpassing 7.1 percent in non-insurance sectors such as banks, cards and securities (Financial Supervisory Service, 2020).

Nevertheless, insurance is an indispensable financial vehicle which complements the social security system and make individuals prepare themselves to a satisfactory level for the risks they might face in their lifetime. In addition, insurance companies contribute to national economy by operating life insurance assets: they effectively invest accumulated premiums paid by customers to deliver investment returns with shareholders and customers. Due to the long duration of life insurance assets, those are invested in major industries such as national infrastructure, which can contribute to national economic development (Korea Life Insurance Association, 2021). Therefore, it is very important for individuals as well as countries to ensure that customers understand insurance as a financial vehicle correctly and prepare for their future using it. Also, insurance companies need to maintain long-term positive relationships with customers and gain a good reputation to secure their business sustainability.

\section{Corporate Social Responsibility}

Beyond the traditional but fragmented value of profit-seeking, corporate objectives have recently highlighted the notion of corporate social responsibility (CSR), including environmental, social and governance factors. Specifically, in order to maintain sound business ecosystem and secure sustainable growth, a corporation should pursue not only financial outcome but also the concept of creating shared value (CSV) which can be characterized as ethics, quality of management, mutual growth with suppliers, eco-friendly products, etc. Mullerat and Brennan (2011) define the concept of the CSR by which organizations respect and protect the interests of a wide range of stakeholders by maintaining a clean environment and a better society. Griffin (2000) describe the concept of CSR as the necessity for companies to fulfill their obligations to protect and enhance their geographical society.

However, it would be difficult to say that it is entirely voluntary for many companies to recognize and pursue CSR. In reality, many companies realize social responsibility only after recognizing public criticism that they have failed to fulfill their social responsibilities (Porter \& Kramer, 2006). Despite this reality, many studies have shown that companies can increase corporate value by fulfilling their social responsibilities. Kook and Kang (2011) argue that companies with particularly good governance structure can increase corporate value such as increased sales and increased reputation by doing CSR activities compared to those with poor governance. Also, Min, Kim, and $\mathrm{Ha}$ (2014) claim that while ESG factors have a negative impact on the share price return in the short term, but can increase corporate value in the long term.

As stated previously, insurance companies price and value financial assets, monitor borrowers, manage financial risks, and provide coverage for the financial consequences from the situation that people usually try to avoid (Scholtens, 2011). By functioning as such, the insurance company affects the society it belongs to (Scott, 2003). However, as CSR has evolved into a key business strategy, many insurance companies are focusing on serving their community more actively in line with the social trend. Through this, insurance companies which need a long-term relationship with customers are able to improve their reputation and enhance customer loyalty (Lee, Chang, \& Lee, 
2017), and can be benefited from improved brand image to increase customer intention to purchase insurance products (Kim, Kim, \& Wu, 2016).

\section{Case Description}

\section{About Prudential Corporation Asia}

PCA is a business unit of Prudential plc, comprising its life insurance operations in Asia and Africa, as well as its asset management business, Eastspring Investments across 14 Asian markets. Its parent company, Prudential plc, has more than 170 years of tradition. It was founded as Prudential Mutual Assurance in London. In the 1912 sinking of the Titanic, Prudential paid insurance claims of $£ 14,239$ for 324 victims, which is onefifth of the total. This case was enough to change people's perception toward insurance.

During the 1920s, Prudential plc began to expand overseas, with the first branch in India in 1923. In 1931, it took the first steps to Singapore as well as Africa in the same year. Prudential plc's international business continued to grow rapidly through the late $20^{\text {th }}$ century. In recognition of the high growth potential, PCA was established in 1994. For over 90 years, Prudential has been providing familiar, trusted financial security to over 16 million customers in Asia and Africa. Today, it is headquartered in London and Hong Kong, serving its customers through 600,000 agents and over 18,000 bank branches. PCA entered South Korea in 2002 to further strengthen its business in Asia and mainly provided variable insurance products to Korean customers until it left in 2017.

\section{What's Cha-Ching?}

Prudence Foundation is the community investment arm of Prudential plc in Asia and Africa. The charitable entity was incorporated in Hong Kong in 2011 and has operated the regional community investment programs of PCA covering both life insurance operations and Eastspring Investments. The non-profit entity established its mission as 'to make a lasting contribution through sustainable initiatives focused on three key pillars: Children, Education, and Disaster Preparedness \& Recovery'.

For the Education pillar, Prudence Foundation developed the Cha-Ching program for financial literacy of children. It aims to build money-smart skills of children and the program uses a series of animated music videos. Originally, the word "Cha-Ching" is the sound of opening and closing a cashier's drawer, but the expression is used when someone generates large profits at a low cost. Proud of Asia's first multi-country, animated, musical edutainment series, it put animated characters which is called Cha-Ching band on the stage. Each member of the band has different approach to money management. Cha-Ching music videos feature catchy songs with lyrics and enhanced subtitles that children can sing along to, aiding comprehension and retention. The core concept that the band teaches to children are how to earn, save, spend and donate money (Figure 1).

Before the launch of the program, Prudential conducted

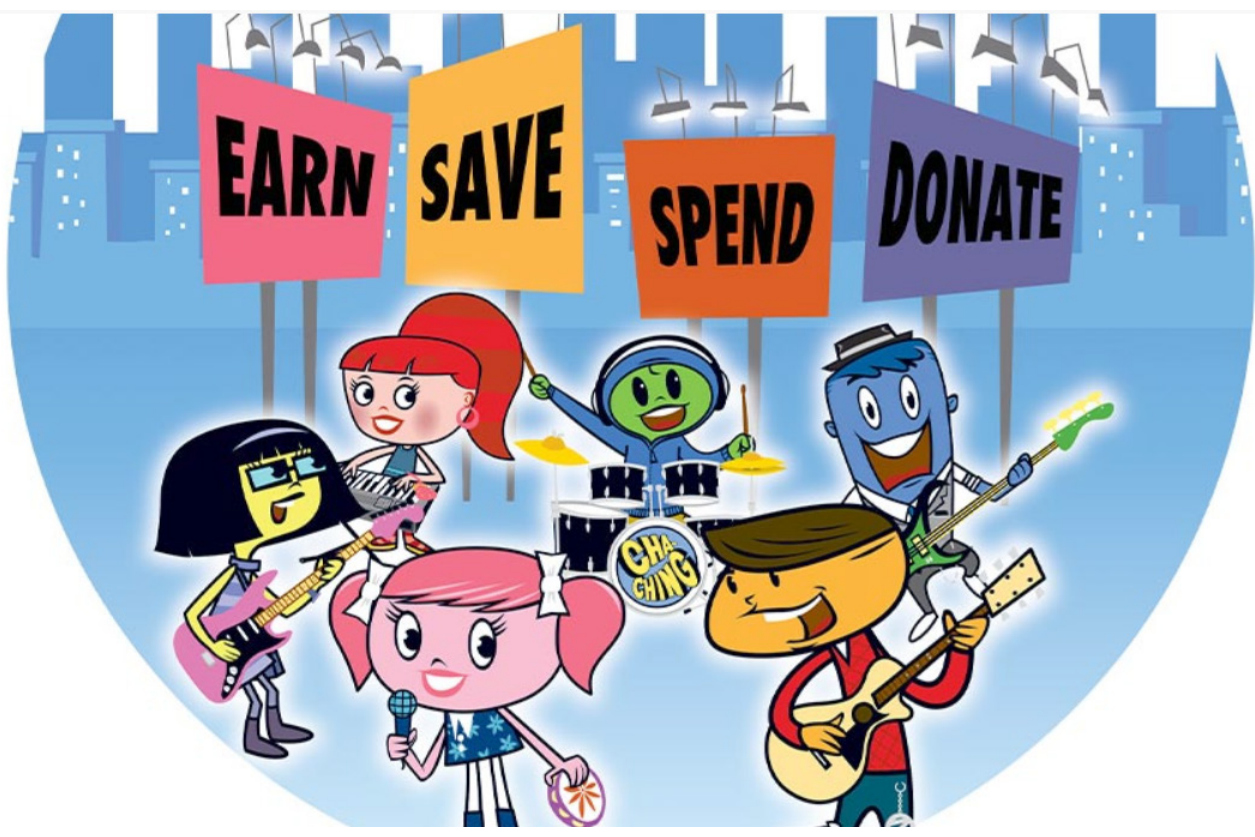

Figure 1. The Cha-Ching band teaches fundamental money management concepts. Adopted from "Cha-Ching financial literacy for children," by Prudential Corporation Asia, 2020. Copyright 2020 by Prudential Corporation Asia. Reprinted with permission. 
research about financial literacy in children across Asia. It revealed that only 13 percent of parents believe that their children possess well-established money management habits whereas 95 percent think it is important to learn them. With regard to the necessity of financial education in childhood, the Organization for Economic Cooperation and Development (OECD) mentioned that financial education should start at school and should be clearly separated from commercial initiatives (OECD, 2006). Also, Amagir, Groot, Brink, and Wilschut (2018) argue that financial education ought to be started in elementary school and need to be repeated in secondary school and college. Prudential Foundation's Cha-Ching program was designed to meet these needs of the community, targeting children aged 7-12 year old. To ensure the content was meaningful and age-appropriate, the company worked with award-winning children's education specialist Dr. Alice Wilder who was known for the development of Blue's Clues. With her expertise, the program adopted the "edutainment" philosophy which makes children learn through play, do what they see, and learn through practice. The program is now available across 10 markets across Asia and Africa.

\section{Integrated Communication through Corporate Social}

\section{Responsibility (CSR) Activities}

One of the noteworthy points of Cha-Ching program is that it has multiple touch points to contact with the target audience. Prudence Foundation describes it as 360-degree platform. Research has suggested that using multiple education media is more effective than single medium in isolation. Specifically, Fisch (2013) argues that cross-platform learning provides benefits for comprehension as well as transfer of learning. Therefore, Cha-Ching was designed with multi-channel involvements to suffice education needs of children. According to PCA (2020), Cha-Ching is built around multiple channels that respond to children's learning needs, which consist of:

- A series of three-minute music videos on Cartoon Network and Free to Air TV.

- A website with games and applications that engage children in real-life money management scenarios to reinforce the learnings derived from the music videos.

- Online resources and at-home activities that teachers and parents can work through with children.

- YouTube playlist to provide additional platforms to access music videos anytime anywhere.

- A Facebook page to encourage interaction and discussion on the social media.

As shown in Figure 2, Cha-Ching music videos have reached over 34 million households through TV cartoon network and Free-to-Air in Asia to date. Also, the Cha-Ching YouTube play-

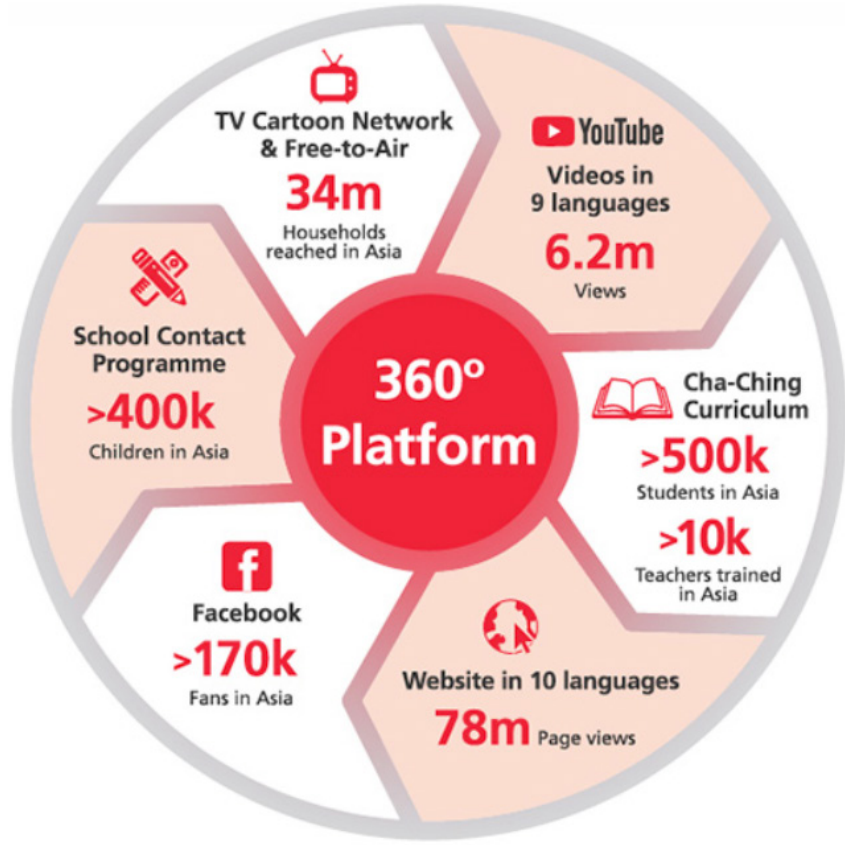

Figure 2. Integrated, 360 degree approach of educational concepts to promote learning. Adopted from "Cha-Ching financial literacy for children," by Prudential Corporation Asia, 2020. Copyright 2020 Prudential Corporation Asia. Reprinted with permission.

list also features music videos in 9 dubbed languages and has 6.2 million views. The Cha-Ching Facebook page has a fanbase of over 170,000 followers so far. Across Asia and Africa, more than 400,000 children have benefited directly from the Cha-Ching School Contact Program, and over 500,000 students have been taught the Cha-Ching curriculum to date (PCA, 2020).

Another differentiation point of the program is that ChaChing uses cartoon characters. Nusir, Alsmadi, Al-Kabi, and Sharadgah (2012) argues that multimedia usage in children education is effective in getting students attention especially when cartoon characters are involved. Stith (2004) investigated the effectiveness of animation usage in education, and claimed that performance is enhanced when animated illustration comes with audio, video, or other multi-media than static illustration.

In recognition of this originality and educational effect, ChaChing has gained international awards for promoting effective financial literacy. The program was named Education Program of the Year in the Excellence in Financial Literacy Education (EIFLE) Awards in Orlando in 2012, and honored as the Best Interstitial Series in the Cynopsis: Kids!magination Awards in New York in June 2012. In Asia, Cha-Ching received the Award for the Most Innovative Financial Education Program by the Institute of Financial Planners Hong Kong in September 2012.

In order to contribute to its community further, Prudence Foundation partnered with JA Asia Pacific in 2016 and devel- 
oped a Cha-Ching curriculum for teachers. It included structured lesson plans to conduct Cha-Ching sessions in school. The curriculum employed activities-based learning approach to instill four key money concepts of Earn, Save, Spend and Donate in students. Since it was launched in 2016, the Cha-Ching curriculum has been endorsed by the Ministry of Education in many Asian countries, such as Philippines, Indonesia, Malaysia, Vietnam, Cambodia, Taiwan, Thailand and Zambia. To date, over 10,000 teachers trained more than 500,000 children with the curriculum across Asia and Africa. Of course, cartoon characters and the 360-degree platform have been used to maximize education performance.

\section{Cha-Ching in Korea}

PCA Korea, a former local business unit of PCA, also accepted the Cha-Ching program and conducted CSR activities using the Cha-Ching contents under the group's guide. Until they pulled out of Korean market in 2017, PCA Korea continued to operate "the Cha-Ching Magic Number Economic Class" for the financial literacy of first and second graders. A total of 40 schools, 363 classes and more than 9,400 children have benefited by participating the program, in conjunction with PCA Korea’s employee volunteering program. In 2015 and 2016, they move one step forward to have Cha-Ching Economic Festival. Parents had the opportunity to attend asset management seminar while their children played and learned with the edutainment series.

\section{Discussion}

Many companies have been engaged in social contribution activities through volunteering or donations. Recently, however, the importance of ESG management, which seeks to fulfill its responsibilities to the community, has become increasingly emphasized beyond conducting single-shot services or donating activities. PCA also recognized the sense of social responsibility and established Prudence Foundation to carry out its responsibility to Asia and Africa communities. Cha-Ching program, one of the key educational strategic focus the foundation has set, is designed for financial literacy with following distinctions:

First, Cha-Ching is a future-oriented program for children. At the global policy level, youth are one of the priority targets for financial education (OECD, 2014). Many researchers have justified the attention placed on children and adolescents in that they need to be prepared to face a more sophisticated financial market and economic education through school program is more cost-effective (Frisancho, 2020). In this regard, PCA's ChaChing can be said to be an investment in the next generation, aligning with the business characteristics. Fostering a genera- tion with the right concept of money is not only a contribution to a healthy society, but also a long-term investment to the future business of insurance companies.

Second, the program takes advantage of animation characters to appeal target audience. Owing to technological advances, education is moving from pen-and-paper correspondence courses to more interactive and integrated environment. In fact, many visual learning materials such as animation characters are widely used in education sites and research has confirmed the effectiveness of interactive learning materials (Islam, Ahmed, Islam, \& Shamsuddin, 2014). Catered toward children, ChaChing characters were introduced to eliminate boredom and intricacy. Children feel familiarity with the cartoon characters and learn from them. The fact that the program is designed to draw participant's interest may be one of the key success factors of Cha-Ching program.

Last, PCA's Cha-Ching education program maximized the effectiveness of the program by using multiple channels rather than a single communication route, which is an important feature differentiated from other social contribution activities. Comprehensive use of TV, YouTube, Facebook, school contact programs, and websites is increasing the educational coverage as well as effectiveness of synergies from various communication channels. As a result, PCA has realized its "edutainment" philosophy that children learn through play for the past 10 years, and they were able to complete their responsibilities as a community member.

\section{Conclusion}

In a capitalist economy, it is very important to have a clear understanding of how an individual should earn, save, spend and donate money from an early age in order to live a flourishing life. PCA, Prudential plc's business unit with more than 90 years of history, has provided a financial education for Asia and Africa society. The education program draws children's attention and participation by adopting Cha-Ching animation characters and promotes learning using integrated, 360 degree platform. To date, numerous children have learned from the edutainment program and this contribution is believed to make communities healthier and help the insurance company foster robust relationships with customers.

\section{References}

Amagir, A., Groot, W., Brink, H. M., \& Wilschut, A. (2018). A review of financial-literacy education programs for children and adolescents. Citizenship, Social and Economics Education, 17(1), 
56-80.

Consumer and Financial Literacy Working Party. (2011, September). National consumer and financial literacy framework. Retrieved from http://www.curriculum.edu.au/verve/_resources/National_ Consumer_Financial_Literacy_Framework_FINAL.pdf

Financial Supervisory Service (2020, December 30). 2020 Customer protection evaluation results. Retrieved from https://www.fss. or.kr/fss/kr/promo/bodobbs_view.jsp?seqno=23580\&no=18\&s_ title $=\% \mathrm{BD} \% \mathrm{C} 7 \% \mathrm{C} 5 \% \mathrm{C} 2 \% \mathrm{C} 6 \% \mathrm{~F} 2 \% \mathrm{~B} 0 \% \mathrm{~A} 1 \&$ s_kind=title\&page $=1$

Fisch, S. M. (2013). Cross-platform learning: On the nature of children's learning from multiple media platforms. New Directions for Child and Adolescent Development, 2013(139), 59-70.

Frisancho, V. (2020). The impact of financial education for youth. Economics of Education Review, 78, 101918.

Griffin, J. (2000). Corporate social performance: Research directions for the 21st century. Business \& Society, 39(4), 479-491.

Islam, B., Ahmed, A., Islam, K., \& Shamsuddin, A. K. (2014). Child education through animation: An experimental study. International Journal of Computer Graphics \& Animation, 4(4), 43-52.

Kim, S., Kim, H., \& Wu, G. (2016). Effect of consumers' perception of CSR in insurance companies on insurance companies image and insurance product purchase intention. Financial Planning Review, 9(1), 75-98.

Kook, C. P., \& Kang, Y. S. (2011). Corporate social responsibility, corporate governance and firm value. Korean Journal of Financial Studies, 40(5), 713-748.

Korea Life Insurance Association (2021). 2021 What is life insurance? Retrieved from https://exam.insure.or.kr/upload/upfile/ common/recent/varisu_lp_recent.pdf

Lee, C. Y., Chang, W. C., \& Lee, H. C. (2017). An investigation of the effects of corporate social responsibility on corporate repu- tation and customer loyalty - evidence from the Taiwan non-life insurance industry. Social Responsibility Journal, 13(2), 355-369.

Mullerat, R., \& Brennan, D. (2011). Corporate social responsibility: The corporate governance of the 21st century. Alphen aan den Rijn, Netherlands: Kluwer Law International.

Min, J. H., Kim, B., \& Ha, S. (2014). The impact of firms' environmental, social, and governancial factors for sustainability on their stock returns and values. Journal of the Korean Operations Research and Management Science Society, 39(4), 33-49.

Nusir, S., Alsmadi, I., Al-Kabi, M., \& Sharadgah, F. (2012). Studying the impact of using multimedia interactive programs at children ability to learn basic math skills. Acta Didactica Napocensia, 5(2), 17-32.

Organization for Economic Cooperation and Development (2006). The importance of financial education. Policy brief. Retrieved from http://www.oecd.org/dataoecd/8/32/37087833.pdf

Organization for Economic Cooperation and Development (2014). Financial education for youth: The role of schools. Retrieved from http://www. oecd.org/daf/fin/financial-education/financial-education-for-youth.htm

Porter, M. E., \& Kramer, M. R. (2006). Strategy and society: The link between competitive advantage and corporate social responsibility. Harvard Business Review, 84(12), 78-92, 163.

Prudential Corporation Asia (2020). Cha-Ching financial literacy for children. Retrieved from https://www.prudentialcorporation-asia.com/ corp/prudential-pca/en/prudence-foundation/our-programmes/chaching/

Scholtens, B. (2011). Corporate social responsibility in the international insurance industry. Sustainable Development, 19(2), 143-156.

Stith, B. J. (2004). Use of animation in teaching cell biology. Cell Biology Education, 3(3), 181-188. 